\title{
Call for TERMIS-AP 2020 Special Issue Papers: Revolutionizing Regenerative Research Strategies Towards Precision Medicine
}

\section{Deadline for Manuscript Submission: June 30, 2020}

\author{
Guest Editors: Mohammad Syaiful Bahari Bin Abdull Rasad, PhD; International Islamic University Malaysia; \\ Rajesh Ramasamy, PhD; Universiti Putra Malaysia
}

Tissue Engineering and Regenerative Medicine Society of Malaysia (TESMA) and Tissue Engineering and Regenerative Medicine International Society (TERMIS), the hosts of the TERMIS-AP Chapter Meeting, September 21-24, 2020 , are pleased to announce a dedicated special issue featuring tissue engineering and regenerative medicine research from the Asia Pacific region. The theme of the upcoming TERMIS-AP meeting is "Revolutionizing Regenerative Research Strategies Towards Precision Medicine."

This upcoming TERMIS-AP meeting offers several tracks focusing on advances in tissue engineering, regenerative medicine and stem cells, cells manufacturing, and bioprocess, biomaterials as well as the ethical, legal and social implications within the field.

The Guest Editors of this special issue will consider tissue engineering and regenerative medicine contributions from the full breadth of research in the Asia Pacific region: from original research papers, reviews, and methods papers, to perspectives, profiles, commentaries, and exemplary front matter.

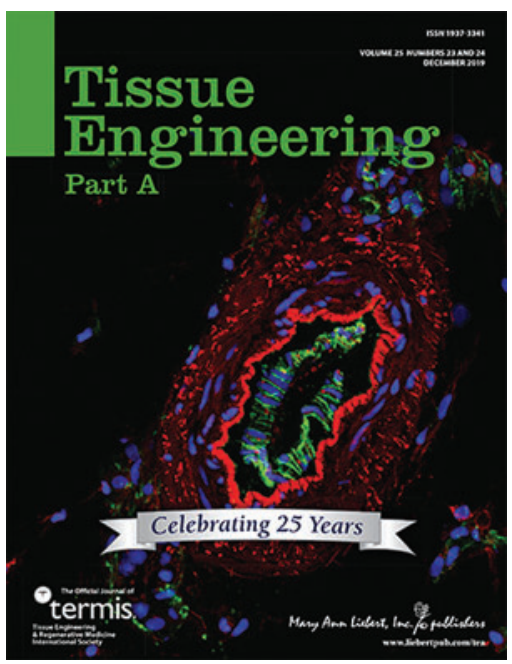

Areas of interest include, but are not limited to the following research within the Asia Pacific region:

\section{A. TISSUE ENGINEERING}

- Recent advances in tissue engineering

- Translating tissue engineering into clinics

- Reconstructive and aesthetic plastic surgery

- Scaffold-free tissue engineering

- Clinical translation of tissue engineering techniques using various biomaterials

- Sports medicine \& rehabilitation

- Revolutionising TERM industry beyond 4.0

\section{B. REGENERATIVE MEDICINE}

- Cell-based regenerative therapy

- Cell-free therapy

- Gene therapy

- Modulation of immune response for tissue regeneration

- Regenerative rehabilitation

- Natural product for regeneration 


\section{CELL MANUFACTURING AND BIOPROCESS}

- Biofabrication

- Cell manufacturing \& banking

- Bioprinting

- Bioreactor technologies in TERM

- Enabling technology in tissue engineering \& regenerative medicine

- Next-gen stem cell

- Cell-integrated biological systems

\section{BIOMATERIALS}

- Scaffold and matrices

- Injectable scaffold

- Bio-3D printing (additive manufacturing)

- Biomaterial for drug delivery

- Biosensors/biochips

- Interactions of biomaterials and stem cells

E. CHALLENGES, ETHICAL, LEGAL AND SOCIAL IMPLICATIONS OF TISSUE ENGINEERING \& REGENERATIVE MEDICINE

- Challenges in TERM

- Ethical aspects

- Regulatory requirements

- Cultural and political dimensions

Contributions will receive prompt and thorough peer review. Please refer to our Instructions for Authors before submitting your manuscript for consideration. Authors are encouraged to vet ideas directly with Assoc. Prof. $\mathrm{Dr}$ Mohammad Syaiful Bahari (syaiful@iium.edu.my) or Assoc. Prof. Dr Rajesh Ramasamy (rajesh@upm.edu.my) via e-mail before submitting.

Tissue Engineering is a distinguished biomedical journal advancing the field with cutting-edge research and applications on all aspects of tissue growth and regeneration. This multidisciplinary journal brings together the principles of engineering and life sciences in tissue development and regenerative medicine. Tissue Engineering is divided into three parts, providing a central forum for groundbreaking scientific research and developments of clinical applications from leading experts in the field that will enable contributions to the ultimate care of patients.

Manuscript Submission Deadline: June 30, 2020

Editorial questions? Contact:

(1) Mohammad Syaiful Bahari Bin Abdull Rasad (Assoc. Prof. Dr), Guest Editor, E-mail: syaiful@iium.edu.my

(2) Rajesh Ramasamy (Assoc. Prof. Dr), Guest Editor, E-mail: rajesh@upm.edu.my

\section{Submit your paper for peer review online: https://mc.manuscriptcentral.com/ten}

